\title{
Bark Extract of Bathysa cuspidata in the Treatment of Liver Injury Induced by Carbon Tetrachloride in Rats
}

\author{
Reggiani Vilela Gonçalves ${ }^{1}$, Sérgio Luis Pinto da Matta $^{2 *}$, Rômulo Dias Novaes ${ }^{3}$, João \\ Paulo Viana Leite ${ }^{4}$, Maria do Carmo Gouveia Peluzio ${ }^{5}$ and Emerson Ferreira Vilela ${ }^{6}$ \\ ${ }^{1}$ Departamento de Biologia Animal; Universidade Federal de Viçosa. ${ }^{2}$ Departamento de Biologia Geral; \\ Universidade Federal de Viçosa. ${ }^{3}$ Departamento de Biologia celular, tecidual e do Desenvolvimento; Universidade \\ Federal de Alfenas; Alfenas- MG - Brasil. ${ }^{4}$ Departamento de Bioquímica e Biologia Molecular; Universidade \\ Federal de Viçosa. ${ }^{5}$ Departamento de Nutrição e Saúde; Universidade Federal de Viçosa. ${ }^{6}$ Departamento de \\ Fitotecnia; Universidade Federal de Viçosa; Viçosa - MG - Brasil
}

\begin{abstract}
The aim of this study was to investigate the effect of bark extract Bathysa cuspidata $(B C E)$ in the reconstitution of hepatic parenchyma and stroma after dysfunction induced by the $C C l_{4}$. Liver lesions were induced by intraperitoneal administration of $\mathrm{CCl}_{4}(1 \mathrm{~mL} / \mathrm{kg})$ every $48 \mathrm{~h}$ for 12 days. The animals were treated with $\mathrm{B}$. cuspidata extract (BCE) administered by gavage for another 12 days. Forty-nine rats were randomized into seven treatment groups with seven animals receiving $\mathrm{CCl}_{4}, B C E(200$, or $400 \mathrm{mg} / \mathrm{kg})$ and the vehicle DMSO alone, or in different combinations. The extract alone showed no evidence of hepatic toxicity. In general, rats acutely exposed to $\mathrm{CCl}_{4}$ without the treatment with BCE presented high ALT and AST serum levels and high tissue content of lipid hydroperoxides, malondialdehyde, and lipid droplets. BCE administration, especially at $400 \mathrm{mg} / \mathrm{kg}$ attenuated significantly all these parameters. Furthermore, the antioxidant activities of the enzymes superoxide dismutase and catalase were significantly increased in the groups receiving this extract. These results showed that the extract of $\mathrm{B}$. cuspidata stem bark stimulated the antioxidant defense system and reduced the morphological and functional liver damage in Wistar rats previously exposed to $\mathrm{CCl}_{4}$.
\end{abstract}

Key words: antioxidant defense, biotechnology, hepatotoxicity, phytotherapy, pathology

\section{INTRODUCTION}

The liver is an important organ responsible for various metabolic processes of detoxification of the organism through a complex enzyme system that regulates the antioxidant liver function (Sanmugapriya and Venkataraman 2006; Ranawat et al. 2010). Liver lesions often reduce its antioxidant defense function and the susceptibility of the organism during exposure to the xenobiotics (Lee et al. 2003). Numerous chemical substances used industrially and pharmacologically may result in an increase over the time the risk of liver lesions. These substances are responsible for a broad spectrum of hepatotoxic effects (Roome et al. 2008). A large percentage of liver disorders occur as a result of exposure to chemical compounds capable of inducing the oxidative stress, which leads to an increase in the production of radical compounds. These compounds may cause oxidative damage to bio-molecules such as proteins and lipids present in the cell membranes, culminating in partial or total loss of cell function (Faremi et al. 2008). In

*Author for correspondence: smatta@ufv.br 
view of its ability to induce the lesions by increasing the chemically reactive species, primarily through the $\mathrm{CCl}_{3^{-}}$radical, carbon tetrachloride $\left(\mathrm{CCl}_{4}\right)$ has been widely used in experimental models of liver toxicity (Brattin et al. 1985; Lee et al. 2003; Hwang et al. 2009). Moreover, it constitutes a reproducible, inexpensive model in which effects are rapid, thus ensuring its frequent use when investigating the effects of vegetable extracts on liver disorders (Khan and Ahmed 2009; Sreelatha et al. 2009).

The treatment of human diseases using the medicinal plants and their derivatives is an ancient practice that is currently gaining popularity worldwide (Eldin and Dunford 2001). At present, there is considerable interest in natural plant products, particularly those used in traditional medicine. These products may be useful in the development of new drug and applications, including liver diseases induced by the toxic agents (Shen et al. 2009; Ye et al. 2009). This type of investigation has been shown to represent an effective strategy for selecting the medicinal plants for the development of new drugs, since around $80 \%$ of the world's population uses the products derived from the plants in their basic healthcare (Farnsworth 1994; Kaur et al. 2005).

Bathysa cuspidata (A. St. Hil.) Hook f. belongs to the Rubiaceae family. The genus Bathysa C. Presl includes approximately 15 species of the trees, small trees and scrubs that are found in Panama, French Guyana, Venezuela, Colombia, Peru, Bolivia and Brazil. In Brazil, there are seven species, all in the South and Southeast region of the Atlantic Rain Forest: $B$. mendoncaei, $B$. cuspidata, B. gymnocarpa, B. sylvestrae, $B$. autralis, $B$. stipulata and $B$. nicholsonii (Germano-Filho 1999). B. gymnocarpa, $B$. sylvestrae, B. australis, B. stipulate and $B$. nicholsonii. B. cuspidata is a plant popularly known in Brazil as "quina-do-mato" and its bark is used in popular medicine for the treatment of stomach and liver disorders, as well as a healing agent. Studies with an ethanolic extract and the dichloromethane fraction of $B$. cuspidata have shown antinociceptive and antiinflammatory effects in albino mice previously treated enterally (Correa 1984). In toxicity tests, ethanolic extracts of the leaves and bark of this species showed no mutagenic effects at the doses tested (Nunes 2008). Studies have demonstrated the preventive effect of the bark extract of B. cuspidata in the injuries to the liver and lung, but its effect in the treatment of previously established lesions remains poorly understood.

Thus, this study used a stereological approach and biochemical analysis to investigate the morphofunctional adaptations in the liver of Wistar rats exposed to $\mathrm{CCl}_{4}$ after treatment with the bark extract of $B$. cuspidata. Considering the relationship between the hepatic structure and function, this study investigated the hypothesis that the bark extract of B. cuspidata could have the ability to reconstitute the hepatic parenchyma and stroma after induction of lesions by $\mathrm{CCl}_{4}$.

\section{MATERIALS AND METHODS}

\section{Preparation and phytochemical analysis of $B$. cuspidata}

The samples of B. cuspidata were collected from a biome of Brazilian Atlantic forest in the municipality of Araponga in the state of Minas Gerais, Brazil $\left(20^{\circ} 43^{\prime} 00.0^{\prime \prime} \mathrm{S}\right.$ e $42^{\circ} 29^{\prime} 10.8^{\prime} \mathrm{W}$, $1.200 \mathrm{~m}$ altitude) and adequately documented in the herbarium of the Federal University of Viçosa under registration no VIC 21559. Stem bark samples were separated, dried for $48 \mathrm{~h}$ at room temperature in a darkened, well-ventilated room, pulverized in a knife mill and stored. The powered air-dried stem bark of $B$. cuspidata $(500 \mathrm{~g})$ was extracted exhaustively with ethanol (95\%) by percolation method. The extract was concentrated under vacuum at $50^{\circ} \mathrm{C}$ using a rotary evaporator and then lyophilized until complete removal of the solvent, yielding an ethanolic extract (139 g). Phytochemistry of the extract was performed on chromatography plates coated with silica gel GF $254^{\circledR}$ (Merck, Darmstadt, Germany) using different mobile phases and detection reagents in accordance with the protocol described by Wagner and Bladts (1996).

\section{Estimation the total amount of total phenolics, proanthocyanidin and total flavonoids}

For the determination of total phenolics and proanthocyanidin contents, powdered stem bark $(1.0 \mathrm{~g})$ was extracted with $200 \mathrm{~mL}$ of water at $100^{\circ} \mathrm{C}$ under reflux for $30 \mathrm{~min}$. After heating, the extract was cooled and transferred to a $250 \mathrm{~mL}$ volumetric flask and made up to the volume with water. The extract was left to stand and filtered through the qualitative filter paper. The filtrate was used for the quantification of total polyphenols and of proanthocyanidin contents. 
The concentration of total phenolics was determined colorimetrically, using the FolinCiocalteau method, as described by Verza et al. (2007).

The estimation of total phenolics was expressed as milligrams of pirogalol equivalents per gram of dry matter $(\mathrm{dm})$. For this purpose, $5.0 \mathrm{~mL}$ of filtrate was transferred to a $50 \mathrm{~mL}$ volumetric flask and made up to the volume with water. A 1.0 $\mathrm{mL}$ aliquot of this extract was added to $6.0 \mathrm{~mL}$ of distilled water, followed by the addition of $2.0 \mathrm{~mL}$ of Folin-Ciocalteu reagent and $1.0 \mathrm{~mL}$ of an aqueous $15 \%$ solution of sodium carbonate. After $30 \mathrm{~min}$ at ambient temperature, the absorbance was measured at $760 \mathrm{~nm}$ using a UV-visible spectrophotometer.

The proanthocyanidin content was determined by the procedure of Price et al. (1980). One milliliter of the filtrate was mixed with $5.0 \mathrm{~mL}$ of the $1 \%$ vanillin reagent (equal parts of vanillin-methanol solution and $8 \%$ hydrochloric acid). The mixture was allowed to stand for $20 \mathrm{~min}$. The absorbance of the sample and standard were measured at 500 $\mathrm{nm}$ and the proanthocyanidin was expressed as the milligrams of catechin equivalents per gram of dry matter. The total content of flavonoids was determined by using rutin as a reference compound. This method was based on the formation of flavonoid-aluminium trichloride complexes with a maximum absorption at $420 \mathrm{~nm}$. It was added to $5.0 \mathrm{~mL}$ of methanol extract $(1.0 \mathrm{~g}$ per $200 \mathrm{~mL}$ methanol) and then $0.6 \mathrm{~mL}$ of acetic acid, $10 \mathrm{~mL}$ of methanol, $2.5 \mathrm{~mL}$ of aluminum chloride hexahydrate in $8 \%$ methanol were added and made up to a total volume of $25 \mathrm{~mL}$ with distilled water. After a 15-minute interval, the absorbance was read on a spectrophotometer. The absorption of a standard rutin solution in methanol was measured under the same conditions. All the determinations were performed in triplicate and the results were averaged.

\footnotetext{
Animals

Male Wistar rats with a mean weight of $235 \mathrm{~g}$ were kept in an experimental animal house under the controlled light (12 h light/darkness cycles) and temperature $\left(21 \pm 2^{\circ} \mathrm{C}\right)$ conditions, with relative air humidity of 60 to $70 \%$. Water and standard rat chow were supplied ad libitum. All the procedures involved in the experimental protocol were approved by the Ethics Committee for the Care and Use of Laboratory Animals of the Federal University of Minas Gerais (UFMG) and were in
}

accordance with the Guiding Principles in the Use of Animals in Toxicology adopted by the American Society of Toxicology in July, 1989 and revised in December 2008.

\section{Chemicals}

Carbon tetrachloride $\left(\mathrm{CCl}_{4}\right)$, dimethyl sulfoxide (DMSO), thiobarbituric acid (TBA), formaldehyde and glutaraldehyde were acquired from the Sigma Chemical Co. (St. Louis, MO, USA). The diagnostic kits used in the evaluation of aspartate aminotransferase (AST), alanine aminotransferase (ALT), gamma glutamyl transferase (GGT) and alkaline phosphatase (ALP) were acquired from human in vitro diagnostics (Itabira, Brazil) and the kits for bilirubin measurement were obtained from Labtest (São Paulo, Brazil). Superoxide dismutase (SOD) activity was measured using a commercial kit (Cayman Chemical Company, Ann Arbor, MI, USA).

\section{Experiment}

Liver lesions were induced in the animals in groups 1, 2, 3, 5 and 6 by intraperitoneal administration of $\mathrm{CCl}_{4}(1.0 \mathrm{~mL} / \mathrm{kg}, 60 \%$ in olive oil, v/v) every $48 \mathrm{~h}$ for 12 days. The ethanolic extract of the stem bark of B. cuspidata (BCE) was re-suspended in $700 \mu \mathrm{L}$ DMSO (w/v), and administered to the animals by gavage. The treatment with this extract at doses of either 200 $\mathrm{mg} / \mathrm{kg}$ of body weight (BCE 200), or $400 \mathrm{mg} / \mathrm{kg}$ of body weight (BCE 400) began immediately after the final application of $\mathrm{CCl}_{4}$ and was given daily for 12 days. The same protocol used for the groups receiving the extract was followed in the group receiving DMSO vehicle alone. Forty-nine rats were randomized into seven treatment groups with seven animals in each. $\mathrm{G1}: \mathrm{CCl}_{4}+12$ days without treatment; $\mathrm{G} 2: \mathrm{CCl}_{4} ; \mathrm{G} 3: \mathrm{CCl}_{4}+\mathrm{DMSO}$ $(700 \mu \mathrm{L})$; G4: BCE 400; G5: $\mathrm{CCl}_{4}+\mathrm{BCE} 200$; G6: $\mathrm{CCl}_{4}+\mathrm{BCE} 400$; and G7: only DMSO (700 $\mu \mathrm{L})$. All the animal groups were euthanized $48 \mathrm{~h}$ following the administration of the final treatment, except G1, which was euthanized 12 days after the termination of $\mathrm{CCl}_{4}$ administration to investigate the spontaneous recovery of the liver tissue.

\section{Biochemical analysis and histopathology}

Forty-eight hours following the end of treatment, the animals were anesthetized with ketamine (10 $\mathrm{mg} / \mathrm{kg}$ of body weight) and xylazine $(2.0 \mathrm{mg} / \mathrm{kg}$ of body weight) and euthanized by cardiac puncture. 
Aliquots of the blood were collected and centrifuged at $3000 \mathrm{rpm}$ for $15 \mathrm{~min}$ and the serum was immediately used for the biochemical measurements of AST, ALT, ALP, GGT and bilirubin levels. Serum samples were processed in accordance with the instructions supplied by the manufacturers of the diagnostic kits. For histopathological analysis and biochemical evaluation of the liver tissue, a median incision was made and the liver was removed intact and weighed using the analytical scales. Then two fragments of the liver of each animal were quickly removed, one of which was frozen in liquid nitrogen $\left(-196^{\circ} \mathrm{C}\right)$ and the other immersed in Karnovsky's fixative solution. Aliquots of $500 \mathrm{mg}$ of the frozen liver fragments were homogenized in phosphate buffered saline (PBS) and centrifuged at $5000 \mathrm{rpm}$ at $5^{\circ} \mathrm{C}$. The supernatant was then used for the analysis of superoxide dismutase (SOD) and catalase (CAT). Catalase was evaluated according to Aebi's method (1984) by measuring the rate of decomposition of hydrogen peroxide $\left(\mathrm{H}_{2} \mathrm{O}_{2}\right)$. Lipid peroxidation in the liver homogenate was assessed by malondialdehyde (MDA) detection as previously described by Gutteridge and Halliwell (1990) and by measuring the lipid hydroperoxides using the methodology of Nourooz-Zadeh et al. (1994). Total protein levels were measured using the Bradford method (Bradford 1976).

For histopathology, the fragments of liver were fixed in Karnovsky's solution for $24 \mathrm{~h}$, then dehydrated in ethanol and embedded in methacrylate (Leica, Germany). Sections (4 $\mu \mathrm{m}$ thick) were cut with a Multicut 2045® rotary microtome (Reichert-Jung, Germany), stained in toluidine blue and hematoxylin-eosin, and mounted using Entellan ${ }^{\circledR}$ mounting medium (Merck, Germany). Seventy photomicrographs taken under 20x magnification were obtained for each group with the use of a BX-60® light microscope (Olympus, Tokyo, Japan). Digitalized images were used to detect the presence of inflammatory infiltrate and areas of necrosis. Histomorphometry was performed to evaluate the lipid droplets within the hepatocytes (\% of the histological area) using the Image Pro-plus $4.5 \circledR$ software program (Media Cybernetics, Silver Spring, USA) (Azevedo et al. 2010). The liver somatic index (LSI), which reflected the weight of the liver as a percentage of total body weight, was calculated in accordance with the following ratio: $\mathrm{LSI}=\mathrm{WL} / \mathrm{BW} \times 100$ in which WL was the weight of the liver and BW represented the total body weight.

\section{Statistical analysis}

The data were expressed as the measures of central trend, means and standard deviations (S.D.). The normalcy of the distribution of the data was verified using the Kolmogorov-Smirnov test. Based on this test, the biochemical data were submitted to unifactorial analysis of variance, oneway ANOVA, followed by the Tukey's test for multiple comparisons. In addition, the KruskalWallis test was used to analyze the histological area of the lipid droplets, with statistical significance established at $\mathrm{p}<0.05$. All the tests were performed using the GraphPad Prism 5.0 ${ }^{\circledR}$ statistical software program (GraphPad Software, Inc, California, USA).

\section{RESULTS}

\section{Phytochemical analysis}

The total phenol and proanthocyanidin content was $58.7 \mathrm{mg} / \mathrm{g}$ of dry matter (expressed as pirogalol) and $37.9 \mathrm{mg} / \mathrm{g}$ dry matter (expressed as catechin), respectively. The total flavonoid content was $3.4 \mathrm{mg} / \mathrm{g}$ dry matter using the rutin calibration curve. The curative action of the BCE could be associated with the presence of secondary metabolites with antioxidant effects, primarily high levels of phenolic compounds.

\section{Body weight and liver weight}

As shown in Table 1, there was no significant variation in the initial weight of the animals in the different groups. The final weight of the animals in group 2 was significantly lower than that of the animals in the other groups ( $\mathrm{p}<0.05)$. The LSI was also significantly higher in the animals in groups 1,2 and 3 compared to the groups that received BCE. There were no statistically significant differences in these variables between the animals in the groups treated with the extract.

\section{Biochemical parameters}

The animals in the groups 1, 3 and 5 had lower serum ALT levels compared to those in the group $2(p<0.05)$, whereas the animals in the groups 4,6 and 7 had lower serum ALT levels compared to those in the other groups $(p<0.05)$. The animals in the group 2 had higher serum AST levels compared to the animals in the other groups $(\mathrm{p}<0.05)$. Groups 1,3 and 6 did not differ among 
themselves but differed from the groups 4 and 5, which showed the lowest values of this enzyme in the blood. Group 7 differed only from the group 2 . There were no statistically significant differences in ALP, or GGT levels between the groups (Table 2). Direct bilirubin levels were significantly higher in the group 2, which differed from the groups 1,3 and $4(\mathrm{p}<0.05)$ (Table 3$)$.

Lipid peroxidation induced by the $\mathrm{CCl}_{4}$ in the rat liver (Table 4) led to a significant increase in the quantity of hydroperoxides $(p<0.05)$ in the animals in the groups 1 and 2 that received $\mathrm{CCl}_{4}$ alone. Values of this marker remained low in the groups 4 and 7 that received BCE and just DMSO. In the group 5, there was a reduction in lipid peroxidation markers following the administration of the extract. Similar results were found in the group $6 \quad(p<0.05)$. With respect to malondialdehyde, no statistically significant differences were found between the animals in the $1,2,3,4$ and 7. On the other hand, there was a reduction in this marker in the animals in the groups 5 and 6 compared to the other groups $(\mathrm{p}<0.05)$.

Table 1 - Biometric parameters of rats exposed to $\mathrm{CCl}_{4}(60 \% \mathrm{v} / \mathrm{v}, 1 \mathrm{~mL} / \mathrm{kg})$ and treated with the bark extract of $B$. cuspidata (200 and $400 \mathrm{mg} / \mathrm{kg}$ ).

\begin{tabular}{lcccc}
\hline Groups / Treatment & Initial Weight $(\mathbf{g})$ & Final weight $(\mathbf{g})$ & ${\text { Weight variation }(\mathbf{g})^{*}}^{\text {LSI }(\%)}$ \\
\hline $\mathrm{G} 1 / \mathrm{CCl}_{4}+12$ & $251.71 \pm 09.69^{\mathrm{a}}$ & $236.85 \pm 17.04^{\mathrm{a}}$ & $-14.86 \pm 14.91^{\mathrm{a}}$ & $5.17 \pm 0.37^{\mathrm{a}}$ \\
$\mathrm{G} 2 / \mathrm{CCl}_{4}$ & $271.42 \pm 20.55^{\mathrm{a}}$ & $212.85 \pm 28.11^{\mathrm{b}}$ & $-58.57 \pm 34.96^{\mathrm{b}}$ & $5.54 \pm 0.31^{\mathrm{a}}$ \\
$\mathrm{G} 3 / \mathrm{CCl}_{4}+\mathrm{DMSO}$ & $257.85 \pm 11.49^{\mathrm{a}}$ & $237.14 \pm 10.59^{\mathrm{a}}$ & $-20.71 \pm 17.42^{\mathrm{a}}$ & $5.02 \pm 0.54^{\mathrm{a}}$ \\
$\mathrm{G} 4 / \mathrm{BCE}^{\mathrm{a}} 400$ & $250.71 \pm 10.57^{\mathrm{a}}$ & $252.85 \pm 19.54^{\mathrm{a}}$ & $2.14 \pm 13.49^{\mathrm{a}}$ & $4.01 \pm 0.43^{\mathrm{b}}$ \\
$\mathrm{G} 5 / \mathrm{CCl}_{4}+\mathrm{BCE} 200$ & $249.71 \pm 08.86^{\mathrm{a}}$ & $252.46 \pm 09.06^{\mathrm{a}}$ & $2.75 \pm 9.06^{\mathrm{a}}$ & $4.05 \pm 0.50^{\mathrm{b}}$ \\
$\mathrm{G} 6 / \mathrm{CCl}_{4}+\mathrm{BCE} 400$ & $274.28 \pm 17.66^{\mathrm{a}}$ & $263.57 \pm 22.67^{\mathrm{a}}$ & $-11.00 \pm 31.28^{\mathrm{a}}$ & $4.12 \pm 0.61^{\mathrm{b}}$ \\
$\mathrm{G} 7 / \mathrm{DMSO}$ & $261.45 \pm 13.49^{\mathrm{a}}$ & $264.33 \pm 11.52^{\mathrm{a}}$ & $-2.88 \pm 8.73^{\mathrm{a}}$ & $4.27 \pm 0.46^{\mathrm{b}}$ \\
\hline
\end{tabular}

$\mathrm{BCE}=$ Bathysa cuspidata extract; $\mathrm{LSI}=$ Liver somatic index. (*)Negative sign indicates weight loss. $\mathrm{G} 1=\mathrm{CCl}_{4}+12$ days; $\mathrm{G} 2=$ $\mathrm{CCl}_{4} ; \mathrm{G} 3=\mathrm{CCl}_{4}+\mathrm{DMSO} ; \mathrm{G}_{4}=\mathrm{BCE} 400 ; \mathrm{G} 5=\mathrm{CCl}_{4}+\mathrm{BCE} 200 ; \mathrm{G} 6=\mathrm{CCl}_{4}+\mathrm{BCE}$ 400; G7= DMSO. Data are expressed as mean \pm S.D. ${ }^{\text {a,b }}$ Different letters in the columns indicate statistical difference between groups (p $\square 0.05$ ), ANOVA one-way.

Table 2 - Serum levels of transaminases in rats exposed to $\mathrm{CCl}_{4}(60 \% \mathrm{v} / \mathrm{v}, 1 \mathrm{~mL} / \mathrm{kg})$ and treated with bark extract of B. cuspidata (200 and $400 \mathrm{mg} / \mathrm{kg}$ ).

\begin{tabular}{lcccc}
\multicolumn{1}{c}{ Groups/ Treatment } & ALT (U/l) & AST (U/l) & ALP (U/l) & GGT (U/l) \\
\hline $\mathrm{G} 1 / \mathrm{CCl}_{4}+12$ & $121.71 \pm 31.13^{\mathrm{a}}$ & $166.57 \pm 42.34^{\mathrm{a}}$ & $244.00 \pm 63.39^{\mathrm{a}}$ & $5.28 \pm 1.89^{\mathrm{a}}$ \\
$\mathrm{G} 2 / \mathrm{CCl}_{4}$ & $217.42 \pm 57.68^{\mathrm{b}}$ & $718.71 \pm 318.02^{\mathrm{b}}$ & $234.14 \pm 133.77^{\mathrm{a}}$ & $5.14 \pm 1.06^{\mathrm{a}}$ \\
$\mathrm{G} 3 / \mathrm{CCl}_{4}+\mathrm{DMSO}$ & $127.57 \pm 50.73^{\mathrm{a}}$ & $166.14 \pm 44.99^{\mathrm{a}}$ & $289.57 \pm 97.82^{\mathrm{a}}$ & $3.71 \pm 0.75^{\mathrm{a}}$ \\
$\mathrm{G} 4 / \mathrm{BCE}_{4} \mathrm{COC}$ & $47.14 \pm 2.19^{\mathrm{c}}$ & $82.00 \pm 2.82^{\mathrm{c}}$ & $198.42 \pm 9.16^{\mathrm{a}}$ & $2.00 \pm 0.01^{\mathrm{a}}$ \\
$\mathrm{G} 5 / \mathrm{CCl}_{4}+\mathrm{BCE} 200$ & $74.42 \pm 10.78^{\mathrm{a}}$ & $72.28 \pm 15.35^{\mathrm{c}}$ & $189.00 \pm 38.23^{\mathrm{a}}$ & $2.57 \pm 0.97^{\mathrm{a}}$ \\
$\mathrm{G} 6 / \mathrm{CCl}_{4}+\mathrm{BCE} 400$ & $49.71 \pm 5.28^{\mathrm{c}}$ & $113.00 \pm 15.73^{\mathrm{a}}$ & $187.71 \pm 36.39^{\mathrm{a}}$ & $2.85 \pm 1.06^{\mathrm{a}}$ \\
$\mathrm{G} 7 / \mathrm{DMSO}$ & $52.11 \pm 6.09^{\mathrm{c}}$ & $90.27 \pm 20.18^{\mathrm{a}, \mathrm{c}}$ & $225.40 \pm 42.37^{\mathrm{a}}$ & $3.80 \pm 1.39^{\mathrm{a}}$ \\
\hline
\end{tabular}

$\mathrm{BCE}=$ Bathysa cuspidata extract; $\mathrm{ALT}=$ alanine aminotransferase; $\mathrm{AST}=$ aspartate aminotransferase; $\mathrm{ALP}=$ alkaline phosphatase; GGT $=\gamma$-glutamyl transferase. $\mathrm{G} 1=\mathrm{CCl}_{4}+12$ days; $\mathrm{G} 2=\mathrm{CCl}_{4} ; \mathrm{G} 3=\mathrm{CCl}_{4}+\mathrm{DMSO} ; \mathrm{G}_{4}=\mathrm{BCE} 400 ; \mathrm{G} 5=\mathrm{CCl}{ }_{4}+$ BCE 200; $\mathrm{G} 6=\mathrm{CCl}_{4}+\mathrm{BCE} 400 ; \mathrm{G} 7=\mathrm{DMSO}$. Data are expressed as mean $\pm \mathrm{SD}$. ${ }^{\text {a.b,c }}$ Different letters in the columns indicate statistical difference between groups ( $\mathrm{p} \square 0.05$ ), ANOVA one-way.

Table 3 - Serum levels of total bilirubin and fractions in rats exposed to $\mathrm{CCl}_{4}(60 \% \mathrm{v} / \mathrm{v}, 1 \mathrm{~mL} / \mathrm{kg})$ and treated with the bark extract of B. cuspidata (200 and $400 \mathrm{mg} / \mathrm{kg}$ ).

\begin{tabular}{|c|c|c|c|}
\hline Groups/ Treatment & D-bilirubin (mg/dl) & I-bilirubin (mg/dl) & T-bilirubin (mg/dl) \\
\hline $\mathrm{G} 1 / \mathrm{CCl}_{4}+12$ & $0.037 \pm 0.018^{\mathrm{a}}$ & $0.523 \pm 0.484^{\mathrm{a}}$ & $0.560 \pm 0.491^{\mathrm{a}}$ \\
\hline $\mathrm{G} 2 / \mathrm{CCl}_{4}$ & $0.137 \pm 0.116^{\mathrm{b}}$ & $0.489 \pm 0.332^{\mathrm{a}}$ & $0.626 \pm 0.343^{\mathrm{a}}$ \\
\hline $\mathrm{G} 3 / \mathrm{CCl}_{4}+\mathrm{DMSO}$ & $0.043 \pm 0.014^{\mathrm{a}}$ & $0.331 \pm 0.542^{\mathrm{a}}$ & $0.374 \pm 0.550^{\mathrm{a}}$ \\
\hline G4/ BCE 400 & $0.013 \pm 0.005^{\mathrm{a}}$ & $0.187 \pm 0.017^{\mathrm{a}}$ & $0.200 \pm 0.016^{\mathrm{a}}$ \\
\hline $\mathrm{G} 5 / \mathrm{CCl}_{4}+\mathrm{BCE} 200$ & $0.054 \pm 0.030^{\mathrm{a} . \mathrm{b}}$ & $0.123 \pm 0.051^{\mathrm{a}}$ & $0.177 \pm 0.051^{\mathrm{a}}$ \\
\hline $\mathrm{G} 6 / \mathrm{CCl}_{4}+\mathrm{BCE} 400$ & $0.054 \pm 0.034^{a . b}$ & $0.197 \pm 0.067^{\mathrm{a}}$ & $0.250 \pm 0.078^{\mathrm{a}}$ \\
\hline G7/ DMSO & $0.032 \pm 0.012^{\mathrm{a}, \mathrm{b}}$ & $0.122 \pm 0.074^{\mathrm{a}}$ & $0.155 \pm 0.074^{\mathrm{a}}$ \\
\hline
\end{tabular}

$\mathrm{BCE}=$ Bathys a cuspidata extract, D-bilirubin= direct bilirubin, I-bilirubin= indirect bilirubin, T-bilirubin= total bilirubin. $\mathrm{G} 1=$ $\mathrm{CCl}_{4}+12$ days; $\mathrm{G} 2=\mathrm{CCl}_{4} ; \mathrm{G} 3=\mathrm{CCl}_{4}+\mathrm{DMSO} ; \mathrm{G} 4=\mathrm{BCE} 400 ; \mathrm{G} 5=\mathrm{CCl}_{4}+\mathrm{BCE} 200 ; \mathrm{G} 6=\mathrm{CCl}_{4}+\mathrm{BCE}$ 400; G7= DMSO. Data are expressed as mean \pm S.D. ${ }^{\text {a.b.c }}$ Different letters in the columns indicate statistical difference between groups (p $\square 0.05$ ), ANOVA one-way. 
Table 4 - Hydroperoxides and Malondialdehyde levels in the liver tissue from rats exposed to $\mathrm{CCl}_{4}(60 \% \mathrm{v} / \mathrm{v}, 1$ $\mathrm{mL} / \mathrm{kg}$ ) and treated with the bark extract of B. cuspidata (200 and $400 \mathrm{mg} / \mathrm{kg}$ ).

\begin{tabular}{lcc}
\hline Groups/Treatment & HPX $(\boldsymbol{\mu g} / \mathbf{m g}$ protein $)$ & MDA $(\boldsymbol{\mu g} / \mathbf{m g}$ protein $)$ \\
\hline $\mathrm{G} 1 / \mathrm{CCl}_{4}+12$ & $654.52 \pm 103.08^{\mathrm{a}}$ & $0.026 \pm 0.018^{\mathrm{a}}$ \\
$\mathrm{G} 2 / \mathrm{CCl}_{4}$ & $755.07 \pm 276.91^{\mathrm{a}}$ & $0.030 \pm 0.019^{\mathrm{a}}$ \\
$\mathrm{G} 3 / \mathrm{CCl}_{4}+\mathrm{DMSO}$ & $187.04 \pm 27.45^{\mathrm{b}}$ & $0.013 \pm 0.012^{\mathrm{a}}$ \\
$\mathrm{G} 4 / \mathrm{BCE} 400_{\mathrm{G}}^{\mathrm{a}} \mathrm{CCl}_{4}+\mathrm{BCE} \mathrm{200}$ & $82.27 \pm 2.92^{\mathrm{d}}$ & $0.021 \pm 0.007^{\mathrm{a}}$ \\
$\mathrm{G} 6 / \mathrm{CCl}_{4}+\mathrm{BCE} \mathrm{400}$ & $72.23 \pm 15.33^{\mathrm{d}}$ & $0.001 \pm 0.000^{\mathrm{b}}$ \\
$\mathrm{G} 7 / \mathrm{DMSO}$ & $97.64 \pm 3.94^{\mathrm{c}}$ & $0.00 \pm 0.00^{\mathrm{b}}$ \\
$\mathrm{GCE}$ & $76.39 \pm 10.25^{\mathrm{d}}$ & $0.02 \pm 0.01^{\mathrm{a}}$ \\
\hline
\end{tabular}

$\mathrm{BCE}=$ Bathysa cuspidata extract, $\mathrm{HPX}=$ hidroperoxides, $\mathrm{MDA}=$ Malondialdehyde. $\mathrm{G} 1=\mathrm{CCl}_{4}+12$ days; $\mathrm{G} 2=\mathrm{CCl}{ }_{4} ; \mathrm{G} 3=\mathrm{CCl}{ }_{4}+$ DMSO; G4= BCE 400; G5 $=\mathrm{CCl}_{4}+\mathrm{BCE}$ 200; G6= $\mathrm{CCl}_{4}+\mathrm{BCE} 400 ; \mathrm{G} 7=\mathrm{DMSO}$. Data are expressed as mean \pm S.D. ${ }^{\text {a.b,c }}$ Different letters in the columns indicate statistical difference between groups (p $\square 0.05$ ), ANOVA one-way.

\section{Antioxidant enzymes}

Regarding the levels of SOD, the lowest values were found in the groups 1 and 2; however, in the groups 5 and 6 , the SOD levels were significantly higher when compared to the animals in the groups 1,2 and $3(p<0.05)$. In the groups 4 and 7 , in which the animals received the extract alone, or DMSO respectively without $\mathrm{CCl}_{4}$, SOD levels were higher compared to the other groups $(\mathrm{p}<0.05)$ (Fig.1). The CAT activity was significantly lower in the group 2, compared to the other groups $(\mathrm{p}<0.05)$ but it was significantly lower in the groups 1, 3, 4 and 7 compared to the groups 5 and $6(\mathrm{p}<0.05)$ (Fig. 2).

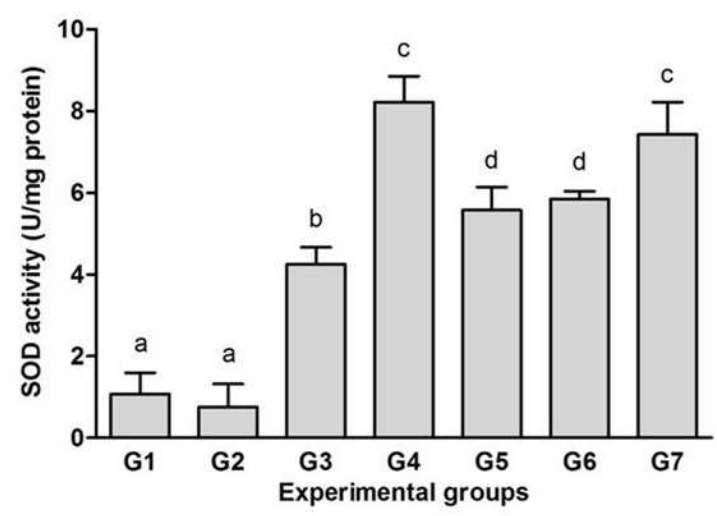

Figure 1 - Activity of Superoxide dismutase (SOD) in the liver tissue from rats exposed to $\mathrm{CCl}_{4}$ $(60 \% \mathrm{v} / \mathrm{v}, 1 \mathrm{~mL} / \mathrm{kg})$ and treated with the bark extract of Bathysa cuspidata (200 and $400 \mathrm{mg} / \mathrm{kg}$ ). $\mathrm{G} 1=\mathrm{CCl}_{4}+12$ days; G2= $\mathrm{CCl}_{4} ; \mathrm{G} 3=\mathrm{CCl}_{4}+\mathrm{DMSO} ; \mathrm{G} 4=\mathrm{BCE} 400$; $\mathrm{G} 5=\mathrm{CCl}_{4}+\mathrm{BCE} 200 ; \mathrm{G} 6=\mathrm{CCl}_{4}+\mathrm{BCE}$ 400; G7 = DMSO. The data are expressed as means \pm S.D. ${ }^{\text {a,b,c,d }}$ Different letters indicate statistical significance between the groups ( $\square$ 0.05), ANOVA one-way.

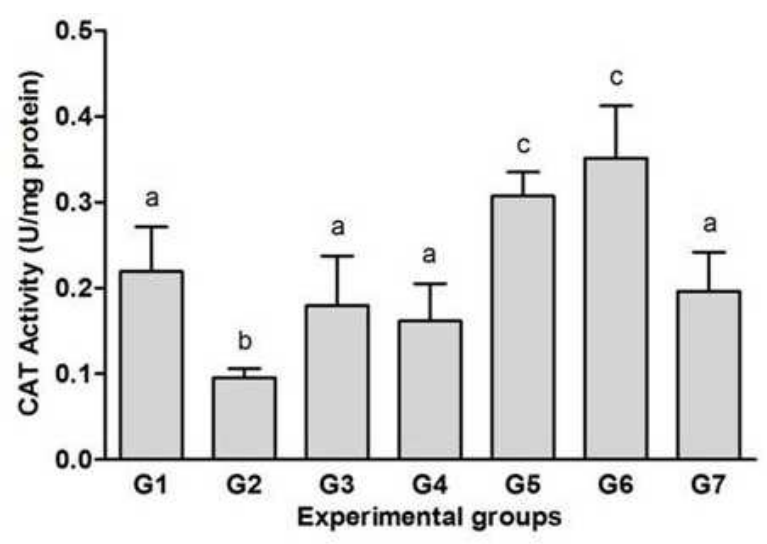

Figure 2 - Activity of Catalase (CAT) in the liver tissue from rats exposed to $\mathrm{CCl}_{4}(60 \% \mathrm{v} / \mathrm{v}, 1$ $\mathrm{mL} / \mathrm{kg}$ ) and treated with the bark extract of Bathysa cuspidata (200 and $400 \mathrm{mg} / \mathrm{kg}$ ). $\mathrm{G} 1=\mathrm{CCl}_{4}+12$ days; $\mathrm{G} 2=\mathrm{CCl}_{4} ; \mathrm{G} 3=$ $\mathrm{CCl}_{4}+\mathrm{DMSO} ; \mathrm{G}_{4}=\mathrm{BCE}$ 400; $\mathrm{G} 5=\mathrm{CCl}_{4}+$ BCE 200; $\mathrm{G} 6=\mathrm{CCl}_{4}+\mathrm{BCE} 400 ; \mathrm{G} 7=\mathrm{DMSO}$. The data are expressed as means \pm S.D. ${ }^{\text {a,b,c }}$ Different letters indicate statistical significance between the groups ( $\square \square 0.05$ ), ANOVA one-way.

\section{Histopathology}

Histopathological alterations such as the accumulation of lipid droplets were found in the three groups in which the animals were not given BCE. Figure 3 showed that the animals in the group 2 had a significantly higher $(\mathrm{p}<0.05)$ percent area of lipid droplets and inflammatory foci compared to the other groups. Figure 4 showed the main changes in the centrolobular region, which were significantly reduced with BCE treatment. In the animals in the groups 1 and 3, the area of lipid droplet formation was significantly larger compared to the groups $4,5,6$ and $7(\mathrm{p}<0.05)$. 

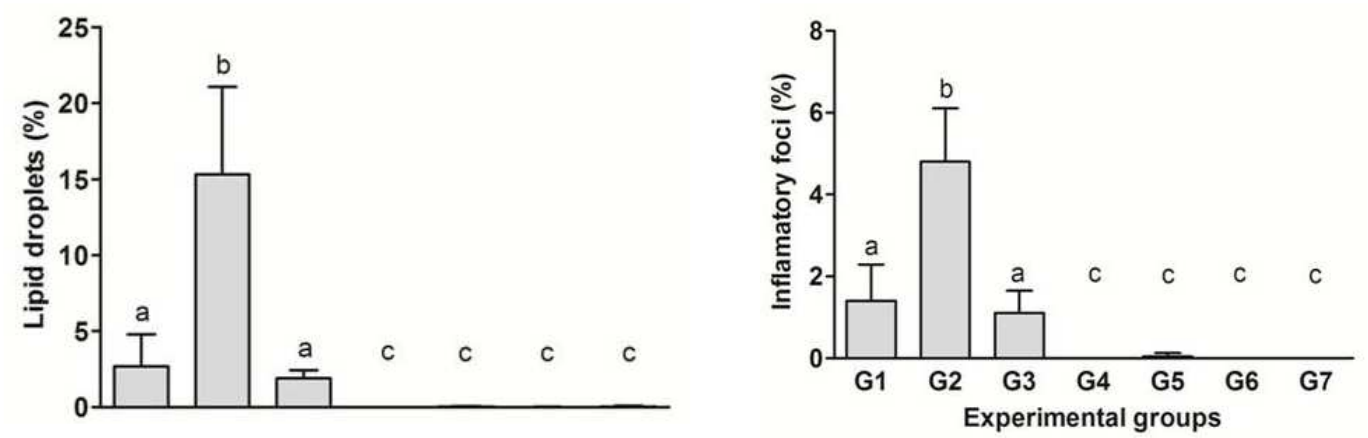

Figure 3 - Distribution of lipid droplets and inflammatory foci in the liver tissue from rats exposed to $\mathrm{CCl}_{4}(60 \% \mathrm{v} / \mathrm{v}, 1 \mathrm{~mL} / \mathrm{kg})$ and treated with the bark extract of Bathysa cuspidata $(200$ and $400 \mathrm{mg} / \mathrm{kg}$ ). $\mathrm{G} 1=\mathrm{CCl}_{4}+12$ days; $\mathrm{G} 2=\mathrm{CCl}_{4} ; \mathrm{G} 3=\mathrm{CCl}_{4}+\mathrm{DMSO} ; \mathrm{G} 4=\mathrm{BCE}$ 400; G5= $\mathrm{CCl}_{4}+\mathrm{BCE} 200 ; \mathrm{G} 6=\mathrm{CCl}_{4}+\mathrm{BCE} 400 ; \mathrm{G} 7=\mathrm{DMSO}$. The data are expressed as means \pm S.D. ${ }^{a, b, c}$ Different letters indicate statistical significance between the groups ( $\left.\mathrm{p} \square 0.05\right)$, Kruskal-Wallis test.
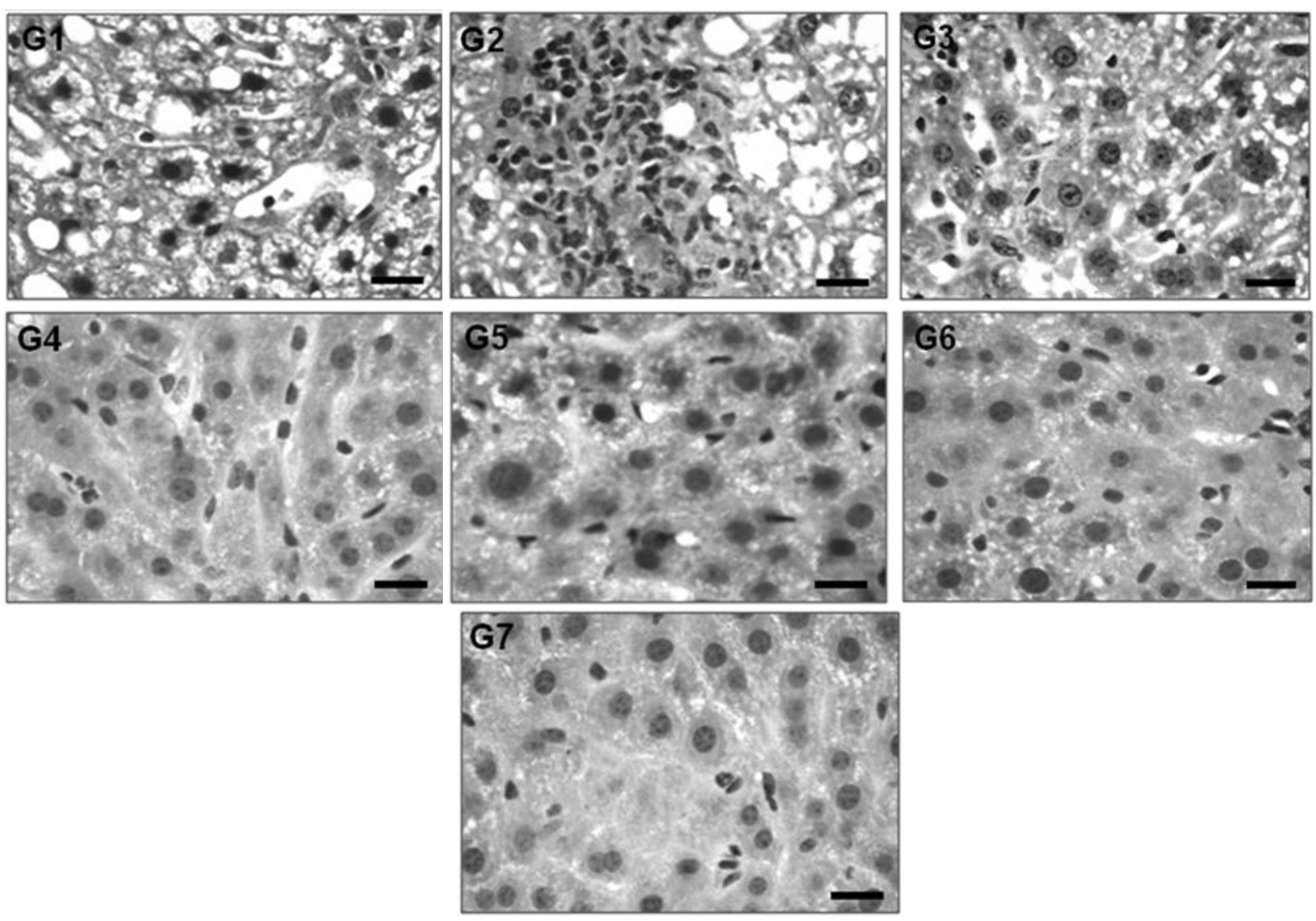

Figure 4 - Representative photomicrography's of the liver tissue from rats exposed to $\mathrm{CCl}_{4}(60 \% \mathrm{v} / \mathrm{v}, 1$ $\mathrm{mL} / \mathrm{kg}$ ) and treated with the bark extract of Bathysa cuspidata (200 and $400 \mathrm{mg} / \mathrm{kg}$ ). Note in G1, G2 and G3 intense damage of the liver tissue with evident lipid droplets deposition. A marked inflammatory infiltrate is observed in $\mathrm{G} 2$. $\mathrm{G} 1=\mathrm{CCl}_{4}+12$ days; $\mathrm{G} 2=\mathrm{CCl}_{4} ; \mathrm{G} 3=$ $\mathrm{CCl}_{4}+\mathrm{DMSO} ; \mathrm{G} 4=\mathrm{BCE} 400 ; \mathrm{G} 5=\mathrm{CCl}_{4}+\mathrm{BCE} 200 ; \mathrm{G} 6=\mathrm{CCl}_{4}+\mathrm{BCE} 400 ; \mathrm{G} 7=\mathrm{DMSO}$.

\section{DISCUSSION}

$\mathrm{CCl}_{4}$ is a known hepatotoxic agent that induces the disorders through the formation of a trichloromethyl radical $\left(\mathrm{CCl}_{3^{-}}\right)$and its peroxyl radical derivative, $\mathrm{CCl}_{3} \mathrm{OO}$-, formed during the metabolism by the phase 1 enzymes present in the endoplasmic reticulum of hepatocytes. The $\mathrm{CCl}_{3}-$ 
and $\mathrm{CCl}_{3} \mathrm{OO}$ - radicals oxidize the unsaturated fatty acids in the plasma membrane of the hepatocytes and cell organelles, leading to the production of lipid peroxyl radicals (LOO-), alkoxy radicals (RO-) and malondialdehyde (MDA), which propagate the oxidative damage in a process, called lipid peroxidation (Wu et al. 2007; Janakat et al. 2008). In addition to their direct toxic effect, lipid peroxides activate an immuno-inflammatory response mediated by the neutrophil chemotaxis, activation of cytokines, chemokines and phospholipases. Both the pathological mechanisms lead to morphological and functional alterations and may result in cell death (Brattin et al. 1985; Geier et al. 2003). In addition to $\mathrm{CCl}_{4}$ exerting an effect on the liver, systemic manifestations such as anorexia, lethargy, malnutrition, and progressive weight loss are common and fibrosis (Kono et al. 2003). In the present study, only the animals in the group 2, euthanized $48 \mathrm{~h}$ after the administration of the final dose of $\mathrm{CCl}_{4}$, experienced a significant reduction in body weight. In addition, the highest indexes of liver hypertrophy, as determined by the LSI, were found in the groups that received $\mathrm{CCl}_{4}$. No variations in the above mentioned variables were found in the groups treated with the extract, or in those treated with the vehicle alone (DMSO). This finding suggested that, although the extract did not contribute towards the increase in body weight gain, it might help reduce the weight loss and liver atrophy induced by $\mathrm{CCl}_{4}$.

From the biochemical point of view, due to the alterations in the membrane permeability and cell death triggered by the lipid peroxidation and inflammatory mediators, increases occur in the serum levels of liver-specific enzymes. Increased levels of enzymes such as ALT, AST, ALP and GGT are indicative of loss of functional integrity of the hepatocyte cell membranes and of liver lesions (Ozer et al. 2008; Ranawat et al. 2010). Moreover, bilirubin evaluation constituted a supplementary method of investigating liver lesions triggered by the $\mathrm{CCl}_{4}$, since this liver toxin is capable of increasing the bilirubin levels by inducing the hepatocellular necrosis and cholestasis (Sanmugapriya and Venkataram 2006; Kumar et al. 2009). The present study revealed an increase in ALT, AST and direct bilirubin in the groups that received $\mathrm{CCl}_{4}$ alone, indicating considerable hepatocellular lesioning, which was confirmed by the histopathology. The administration of $B$. cuspidata extract at the doses used (200 and $400 \mathrm{mg} / \mathrm{kg})$ attenuated the increase in serum levels of these enzymes, resulting in subsequent normalization of these parameters compared to the animals in the groups treated with $\mathrm{CCl}_{4}$ alone, confirming the curative effect of $\mathrm{BCE}$. The experimental model used in this study showed that after the application of $\mathrm{CCl}_{4}$, increases in the levels of these markers occurred, and that 12 days were required to cause significant reductions in the levels of these enzymes (as seen from the values of $\mathrm{G} 1$ and $\mathrm{G} 2$ ).

The curative effect of the bark extract of $B$. cuspidata could be observed from the changes in the parameters of lipid peroxidation and the activity of SOD, an important antioxidant enzyme that catalyzed the conversion of superoxide radicals $\left(\mathrm{O}_{2}-\right)$ to molecular oxygen $\left(\mathrm{O}_{2}\right)$ and oxygen peroxide $\left(\mathrm{H}_{2} \mathrm{O}_{2}\right)$. In the presence of a liver lesion provoked by the $\mathrm{CCl}_{4}$, the SOD and MDA levels reflected the amount of stress caused by the release of free radicals in vivo. As a result of the inflammatory process triggered by the $\mathrm{CCl}_{4}$, the activation of macrophages, neutrophils and hepatic stellate cells occurs, producing a large amount of $\mathrm{O}_{2^{-}}$and, consequently, MDA. This increase in $\mathrm{O}_{2^{-}}$ increases the SOD consumption, resulting in a decrease in its tissue levels (Raja et al. 2007; Hwang et al. 2009). In the present study, animals that received BCE (Groups 5 and 6) had lower levels of MDA compared to those in the other groups, which demonstrated the efficacy of this extract in neutralizing the free radicals and protecting the cell membranes from peroxidation. There was a significant reduction in the activity of the SOD enzyme in the animals in the groups 1 and 2, probably associated with the increase in oxidative stress provoked by the $\mathrm{CCl}_{4}$. The decrease in the SOD was reversed in all the treatment groups, particularly those in which the animals received the plant extract in its different concentrations. The highest SOD values were found in the group that received the plant extract alone (group 4), showing that the extract of $B$. cuspidata stem bark stimulated the SOD activity even in the absence of harmful stimuli. The SOD activity was high in the groups G4 and G7; however, these groups had not previously received $\mathrm{CCl}_{4}$. Similar results for the SOD and MDA have been found for the plants such as Solanum (false "Jurubeba), Artemisia capillaries, and Decalepis hamiltonii, among others, after the application of $\mathrm{CCl}_{4}$ (Dani et al. 2009; Wang et al. 2010; Kuo et al. 2010). Catalase, which catalyzes the 
degradation of $\mathrm{H}_{2} \mathrm{O}_{2}$ to molecular oxygen and water, constituted an additional mechanism of antioxidant defense that is supplementary to that of the SOD activity (Hu et al. 2008). In the present study, CAT activity was lowest in the animals in the group 2, but was also lower in the groups 1,3, 4 and 7 compared to the groups 5 and 6 that received $\mathrm{BCE}$ at both doses. This finding indicated the positive modulating effect of the extract on this enzyme, primarily in the presence of harmful liver stimuli.

In addition to modifications in the antioxidant enzymatic system, treatment with the $\mathrm{CCl}_{4}$ promotes a profound change in the histological architecture of the liver, provoking hemorrhage, leukocyte infiltration, edema, fibrosis, steatosis and necrosis (Kumar et al. 2009; Srivastava and Shivanandappa 2010). In this study, the histological damage to the organ was measured as a function of fat deposition on the liver tissue, which was higher in the groups 1,2 and 3. It has been well established that $\mathrm{CCl}_{4}$ interferes with lipoprotein synthesis as a result of lipid peroxidation and oxidative damage to proteins in the smooth endoplasmic reticulum of hepatocytes, the consequence of this being the accumulation of lipids in the cytoplasm of these cells (microvesicular steatosis), central lobular necrosis and fibrosis (Dani et al. 2008). Liver structure was normal in the groups treated with the bark extract of $B$. cuspidata insofar as the arrangement of the cords of hepatocytes, vascularization and disposition of connective tissue were concerned, thereby indicating the efficacy of the BCE treatment, following the exposure of the liver tissue to $\mathrm{CCl}_{4}$. The architecture of the liver tissue was also normal in the animals of group 4, showing that the administration of the extract alone did not provoke fat deposition in the liver tissue. Together with the analysis of the oxidative stress markers, this finding suggested that the extract helped regulate lipid metabolism by stimulating the enzymatic mechanisms that controlled the oxidative cell damage.

These results showed that the BCE stimulated the antioxidant defense system and reduced the morphological and functional liver damage in the rats exposed to $\mathrm{CCl}_{4}$. Thus, even after severe injuries induced by the $\mathrm{CCl}_{4}$, the extract exhibited remarkable activity in restoring the normal morpho-functional characteristics of the liver. Considering these effects, $B$. cuspidata might potentially play a significant role in the discovery of new drugs for the treatment of liver disease, confirming, in this case, its traditional use in complementary and alternative medicine.

\section{REFERENCES}

Aebi H. Catalase in vitro. Methods Enzymol. 1984; 105: 121-126.

Azevedo MHF, Paula TAR, Matta SLP, Fonseca CC, Costa EP, Costa DS, Peixoto JV. Cell population indexes of spermatogenic yield and testicular sperm reserves in adult jaguars (Panthera onca). Anim Reprod Sci. 2010; 118: 83-88.

Bradford M. A rapid and sensitive method for quantitation of microgram quantities of protein utilizing the principle of protein-dye-binding. Anal Biochem. 1976; 72: 248-254.

Brattin WJ, Glende Jr EA, Recknagel RO. Pathological mechanisms in carbon tetrachloride hepatotoxicity. $J$ Free Radic Bio Med. 1985; 1: 27-38.

Correa MP. Dicionário das plantas úteis do Brasil e das exóticas cultivadas. 1nd Ed. Rio de Janeiro: IBDF; 1984.

Dani C, Oliboni LS, Pasquali MAB, Oliveira MR, Umezu FM, Salvador M, Henrique JAP, Moreira JCF. Intake of Purple Grape Juice as a Hepatoprotective Agent in Wistar Rats. J Med Food. 2008; 11: 127-132

Eldin S, Dunford A. A fitoterapia na atenção primária à saúde. 1nd Ed. São Paulo: Manole; 2001.

Faremi TY, Suru SM, Fafunso MA, Obioha UE. Hepatoprotective potentials of Phyllanthus amarus against ethanol-induced oxidative stress in rats. Food Chem Toxicol. 2008; 8: 2658-2664.

Farnsworth NR. Ethnopharmacology and drug development. Ciba Found Symp. 1994; 185: 42-51.

Geier A, Christoph G, Dietrich SV, Suk-Kyum K, Gerloff T, Gerd A. et al. Effects of proinflammatory cytokines on rat organic anion transporters during toxic liver injury and cholestasis. Hepatol. 2003; 38: 345-354.

Germano Filho, P. Estudos taxonômicos do gênero Bathysa C. Presl. (Rubiaceae, Rondeletieae) no Brasil. Rodriguesia. 1999; 50:345-354.

Gutteridge JMC, Halliwel B. The measurement and mechanism of lipid peroxidation in physiological systems. Trends Biochem. 1990; 15: 129-135.

$\mathrm{Hu}$ XiaO-Ping, Shin Jang-Woo, Wang Jing-Hua, Cho Jung-Hyo, Son Jin-Young, Cho Chong-Kwan. Antioxidative and hepatoprotective effect of CGX, an herbal medicine, against toxic acute injury in mice. $J$ Ethnopharmacol. 2008; 120: 51-55.

Hwang YP, Choi JH, Jeong HG. Protective effect of the Aralia continentalis root extract against carbon tetrachloride-induced hepatotoxicity in mice. Food Chem Toxicol. 2009; 47: 75-81. 
Janakat S, Al-Meire H. Optimization of the dose and route of injection, and characterization of the time course of carbon-tetracloride-induced hepatotoxicity in the rat. J Pharmacol Toxicol Methods. 2008; 48: 41-44.

Kaur S, Michael H, Arora S, Harkonem PL, Kumar S. The in vitro cytotoxic and apoptotic activity of Triphala-an Indian Herbal drug. J Ethnopharmacol. 2005; 67: 249-251.

Khan MR, Ahmed D. Protective effects of Digera muicata (L.) Mart. on testis against oxidative stress of carbon tetrachloride in rat. Food Chem Toxicol. 2009; 47: 1393-1399.

Kono H, Asakawa M, Fuji H, Maki A, Amemiya H, Yamamoto M. Edaravone a novel free radical scavenger, prevents liver injury and mortality in rats administered endotoxin. J Pharmacol Experiment Ther. 2003; 307: 74-82.

Kumar SS, Kumar BR, Mohan GK. Hepatoprotective effect of Trichosanthes cucumerina Var cucumerina $L$. on Carbon tetrachloride induced liver damage in rats. J Ethnopharmacol. 2009; 123: 347-350.

Kuo DH, Kang WH, Shieh PC, Chen FA, Chang CD, Tsai ML, Cheng AC, Ho CT, Pan MH. Protective effect of Pracparatum mungo extract on carbon tetrachloride-induced hepatotoxicity in rats. Food Chem. 2010; 123: 1007-1012

Lee TY, Wang GJ, Chiu JH, Lin HC. Long-term administration of Salvia miltiorrhiza ameliorates carbon tetrachloride-induced hepatic fibrosis in rats. $J$ Pharmacol. 2003; 55: 1561-1568.

Nourooz-Zadeh J, Tajaddini-Sarmadi J, Wolf SP. Measurement of plasma hydroperoxide concentrations by the Ferrous oxidation-xilenol orange assay in conjunction with thiphenylphosphine. Anal Biochem. 1994; 220: 403-409.

Nunes LG. Avaliação de mutagenicidade in vitro e prospecção fitoquímica de três espécies vegetais: Strychnos pseudoquina A. St.- Hil., Coutarea hexandra (Jacq) K. Schum e Bathysa cuspidata (A. St.-Hil) Hook. [M.S. Thesis]. Viçosa, Brazil: Federal University of Viçosa; 2008.

Ozer J, Ratner M, Shaw M, Bailey W, Schomaker S. The current state of serum biomarkers of hepatotoxicity. Toxicol. 2008; 245: 194-205.

Price ML, Hagerman AE, Butler LG. Tannin content of cowpeas, chickpeas, pigeon peas and mung beans. J Agric Food Chem. 1980; 28: 459-461.

Raja S, Nazeer Ahamed KFH, Kumar V, Kakali Mukherjee A, Bandyopadhayay PKM. Antioxidant effect of Cytisus against tetrachloride treated liver injury in rats. J Ethnopharmacol. 2007; 109: 41-47.
Ranawat L, Bhatt J, Patel J. Hepatoprotective activity of ethanolic extracts of bark of Zanthoxylum armatum DC in $\mathrm{CCl}_{4}$ induced hepatic damage in rats. $J$ Ethnopharmacol. 2010; 127: 777-780.

Roome T, Dar A, Ali S, Naqvi S, Choudhary MI. A study on antioxidant, free radical scavenging, antiinflammatory and hepatoprotective actions of Aegiceras corniculatum (stem) extracts. J Ethnopharmacol. 2008; 118: 514-521

Sanmugapriya E, Venkataraman S. Studies on hepatoprotective and antioxidant actions of Strychnos potatorum Linn. seeds on $\mathrm{CCl}_{4}$-induced acute hepatic injury in experimental rats. J Ethnopharmacol. 2006; 105: 154-160.

Shen X, Tang Y, Yang R, Yu L, Duan J. The protective effect of Zizyphus jujube fruit on carbon tetrachloride-induced hepatic injury in mice by antioxidative activities. Food Chem Toxicol. 2009; 122: 555-560.

Sreelatha S, Padma PR, Umadevi M. Protective effects of Coriandrum sativum extracts on carbon tetrachloride-induced hepatotoxicity. Food Chem Toxicol. 2009; 47: 702-708.

Srivastava A, Shivanandappa. Hepatoprotective effect of the root extract of Decalepis hamiltonii against carbon tetrachloride-induced oxidative stress in rats. Food Chem. 2010; 118: 411-417.

Wagner H, Bladts S. Plant drug analysis: a thin layer chromatography atlas. 2nd Ed. Berlin: Springer; 1996.

Wang X, Hai CX, Liang X, Yu SX, Zhang W, Li YL. The protective effects of Acanthopanax senticosus Harms aqueous extracts against oxidative stress: Role of Nrf2 and antioxidant enzymes. J Ethnopharmacol. 2010; 127: 424-432.

Wu Y, Li L, Wen T, Li Y-Q. Protective effects of echinacoside on carbon tetrachloride-induced hepatotoxicity in rats. Toxicol. 2007; 232: 50-56.

Verza SG, Kreinecker MT, Reis V, Henriques AT, Ortega GG. Evaluation of analytical variables of the Folin-Ciocalteu method for the quantitation of the total tannins content using a Psidium guajava L. leaves aqueous extract as a model. Quím Nova. 2007; 30: 815-820.

Ye X, Feng Y, Tong Y, Ng KM, Tsao S, Lau GK, Sze C, Zhang Y, Tang J, Shen J, Kobayashi S. Hepatoprotective effects of Coptidis rhizoma aqueous extract on Carbon tetrachloride-induced acute liver hepatotoxicity in rats. J Ethnopharmacol. 2009; 124: 130-136. 